Удк 635.649:631.543.2:631.559

DOI: $10.31395 / 2310-0478-2021-2-9-12$

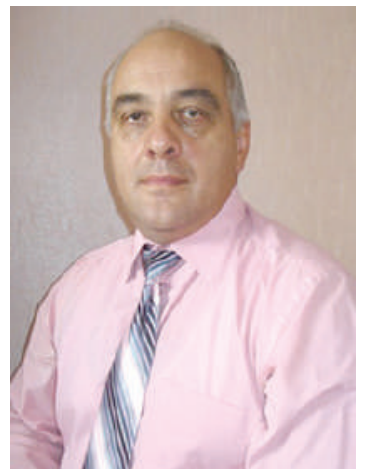

\title{
С.А. Вдовенко,
}

доктор сільськогосподарських наук, професор кафедри

лісового, садово-паркового господарства, садівництва

та виноградарства Вінницького національного аграрного

університету,

м. Вінниця, Україна

E-mail: sloi@i.ua

А.Б. Оплаканська, студент Вінницького національного аграрного університету, спеціальність: Садово-паркове господарство.

м. Вінниця, Україна

E-mail: oplakanska2001@gmail.com

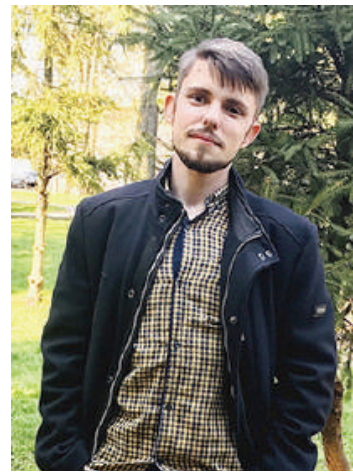

\section{П.А. Швидкий,}

аспірант кафедри лісового, садово-паркового

господарства, садівництва та виноградарства

Вінницького національного аграрного університету,

м. Вінниця, Україна

E-mail: pavlo-shvydkij@ukr.net

O.I. Мулярчук, кандидат сільськогосподарських наук, доцент кафедри садівництва та виноградарства Подільського державного аграрно-технічного університету, м. Кам'янець-Подільський, Україна E-mail: main@pdatu.edu.ua
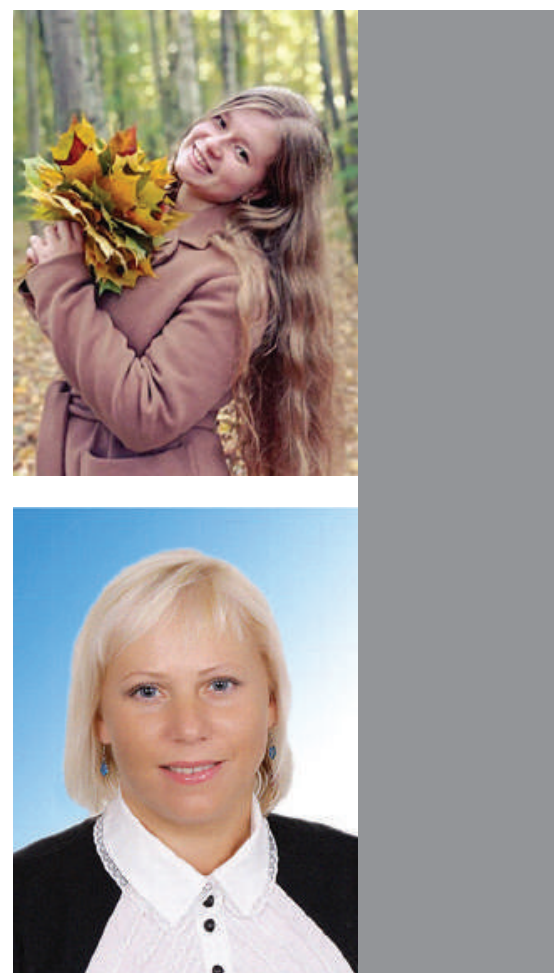

\section{ВПЛИВ СХЕМИ РОЗМІЩЕННЯ I ГУСТОТИ РОСЛИН НА БІОМЕТРИЧНІ ПОКАЗНИКИ ТА УРОЖАЙНІСТЬ ПЕРЦЮ СОЛОДКОГО}

У дослідженнях використовувався ранньостиглий сорт перцю солодкого Афродіта, призначений для споживання у свіжому вигляді. 3 метою вивчення впливу схеми розміщення рослин перцю солодкого на урожайність і біометричні показники обрано рядкову схему $70 \times 15$ см, 70×20, 70×30 см та стрічкову 90+50×20 см. Контролем слугували рослини перцю солодкого, які висаджували за схемою $70 \times 20 \mathrm{~cm}$.

Застосування стрічкової 90+50×20 см та рядкової схеми розміщення $70 \times 15$ см забезпечує збільшення висоти рослини до 39, 1 та 36 см відповідно, або ж перевищує показник контролю на 20,4 та 4,3 \%. Одночасно, більший діаметр стебла отримано за використання рядкової схеми посадки 70х15 см та стрічкової 90+50×20 см. Загальна кількість плодів із застосуванням стрічкової схеми 90+50×20 см збільшується до 6,8 шт. Плоди відповідають сортовим вимогам, мають типове забарвлення та знаходились у технічній стиглості. Найбільшу масу плоду отримано за використання стрічкової схеми

90+50×20 см де показник маси знаходився на рівні 130,7 г.

Найвищою загальною врожайністю характеризувався варіант, де рослини висаджувалися за стрічкової схеми розміщення $90+50 \times 20$ см, де врожайність досягала рівня 30 т/га. Коефіцієнт стабільності Левіса знаходився у межах від 1,07 до 1,16, що засвідчує типовість технології вирощування для даної зони.

Ключові слова: перець солодкий, урожайність, біометрія, схеми посадки.

\section{Vdovenko S.A.,}

Doctor of Agricultural Sciences, Professor of the Department of Forestry, Landscape Gardening, Horticulture and Viticulture of Vinnytsia National Agrarian University, Vinnytsia, Ukraine

E-mail: sloi@i.ua.

Shvydkyi P.A.,

Postgraduate Student of the Department of Forestry, Landscape Gardening, Horticulture and Viticulture of Vinnytsia National Agrarian University Vinnytsia, Ukraine

E-mail: pavlo-shvydkij@ukr.net.

Oplakanska A.B.,

Student of Vinnytsia National Agrarian University, specialty: Landscape Gardening Vinnytsia, Ukraine

E-mail: oplakanska2001@gmail.com.

Muliarchuk O.I.

Phd of Agricultural Sciences, Associate Professor of Horticulture and Viticulture, Podolsk State Agrarian Technical University

Kamyanets-Podilsky, Ukraine.

E-mail: main@pdatu.edu.ua.

\section{INFLUENCE OF PLANTING SCHEME ON BIOMETRIC INDICATORS AND YIELD OF SWEET PEPPER}

In the research sweet pepper Aphrodite of early ripening has been used for fresh consumption. To study the influence of sweet pepper planting schemes on the yield and biometric indicators, a line planting scheme of $70 \times 15 \mathrm{~cm}$ has been chosen; $70 \times 20 \mathrm{~cm} ; 70 \times 30 \mathrm{~cm}$ and 
tape $90+50 \times 20 \mathrm{~cm}$. For verification we take into consideration sweet pepper planted according to the scheme $70 \times 20 \mathrm{~cm}$.

The values of biometric indicators significantly depended on the scheme of planting: the more optimal it was, the better the biometric indicators were. The height of sweet pepper plants in the fruiting phase differed depending on the chosen scheme. As a result of applying the tape scheme of planting $90+50 \times 20 \mathrm{~cm}$ and scheme of planting $70 \times 15 \mathrm{~cm}$, the height of the plant was maximum and reached 39,1 $\mathrm{cm}$ or $36 \mathrm{~cm}$ and exceeded the control rate by 20,4 and 4,3\%, respectively. The larger diameter of the stem was obtained in variants using a row scheme of planting $70 \times 15 \mathrm{~cm}$ and tape $\mathrm{cm}$, in which the indicator was 9,3-9,5 $\mathrm{mm}$.

The amount of fruit on the plant depends on the planting scheme. In the control variant, the total number of fruit was 5,2 pieces, and in the variants of the experiment using the tape scheme $90+50 \times 20 \mathrm{~cm}$, the amount of fruits increased up to 6.8 pieces. The fruits met the varietal requirements, had a typical colour, and stayed in technical maturity.

In our researches the fruit in shape and ripening period corresponded to the technical characteristics of the variety, but the average weight of the fruit was variable. The lowest fruit weight was obtained in the variant using the row scheme of planting seedlings $70 \times 20 \mathrm{~cm}$. However, the largest fruit weight was characterized by plants which were planted according to the tape scheme $90+50 \times 20 \mathrm{~cm}$, where the mass was $130,7 \mathrm{~g}$ and exceeded the control value by 5,2\%.

The highest total yield was characterized by the variant where the plants were planted according to the tape planting scheme $90+50 \times 20$ $\mathrm{cm}$. In this variant, the yield was $30 \mathrm{t} / \mathrm{ha}$ and exceeded the control by $17,6 \%$. As a result of applying the row scheme of planting $70 \times 30$ $\mathrm{cm}$ productivity on size conceded to an indicator of a control variant by $0,4 \%$ and made only $24,6 \mathrm{t} / \mathrm{ha}$.

The Lewis stability coefficient lies in the range from 1,07 to 1,16, that indicates the typicality of cultivation technology for this area. As a result of applying the row scheme of planting of seedlings $70 \times 20 \mathrm{~cm}$ or $70 \times 15 \mathrm{~cm}$ the indicator increases to the size of 1,07 and 1,16 consequently.

Key words: sweet pepper, yield, biometrics, planting schemes.

Постановка проблеми. Основним положенням «Концепції Державної цільової програми розвитку овочівництва на період до 2025 року» передбачено забезпечення громадян України високоякісною овочевою продукцію обсягом 15 млн т, а також підвищення обсягів експорту до 300 тис т. У домогосподарствах споживання овочевої продукції на одного мешканця в місяць становить 9,3 кг або $16 \%$ від продовольчого кошика, а річна потреба населення у овочевій продукції становить 7-7,5 млн т [1].

В Україні існує ряд проблем, які гальмують розвиток галузі овочівництва. Існуюча овочева логістика призводить до значних втрат, зокрема через те, що овочева продукція, в основному, доставляється автотранспортом, проте як у інших країнах активно використовують залізничний, авіаційний та річковий транспорт. В Україні практично не функціонують овочеві кооперативи, що призводить до відсутності розосереджування товаропотоків і в наслідок чого знижується товарність галузі [1].

Аналіз останніх досліджень і публікацій. Перець солодкий - цінна і популярна культура, яка має економічне значення для багатьох країн, вирощується розсадним методом у відкритому та закритому ґрунті. Перець солодкий має високі поживні, смакові та технологічні властивості. У світі щорічне товарне виробництво перцю солодкого становить понад 22 млн т, однак 57 \% від загальних площ вирощування зосереджені в Азії. В Україні виробництво плодів перцю солодкого становить 150 тис т на рік $[2,3]$.

Розсаду перцю солодкого вирощують у спорудах закритого ґрунту. У Лісостепу України насіння на розсаду висівають у другій декаді березня, а пікірування проводять у фазі добре розвинених сім'ядольних листочків. у відкритий ґрунт розсаду висаджують у період, коли верхній шар ґрунту прогрівається до $12-14{ }^{\circ} \mathrm{C}$, такі показники у Лісостепу настають у третій декаді травня [4].

Одним із основних технологічних заходів, які впливають на урожайність рослини, вважають правильне її розміщення на одиниці площі. Розсаду перцю солодкого можна висаджувати як рядковим, так і стрічковим способом за схемою розміщення $50+90$ см або з шириною міжрядь 70 см та відстанню у рядку 15-20 см, заглиблюючи у ґрунт рослини на рівень сім'ядоль. Ґрунт навколо кореневої системи ущільнюють. Перевагою стрічкової схеми $\epsilon$ формування широких міжрядь, що забезпечує механізоване розпушування ґрунту та підживлення рослин. Одночасно за стрічкового способу висаджування підвищується рівень механізації виробничих процесів і створюються кращі умови для роботи збиральних комплексів $[3,4]$.

у сучасних умовах ефективним вважають механізований спосіб висаджування розсади, під час якого значно скорочуються затрати праці від 200-250 до 50-60 люд.-год. на 1 га, забезпечується прямолінійність рядків, розсада краще приживається, що дає змогу надалі застосовувати догляд за рослинами за допомогою комплексу спеціалізованих машин із шириною захвату 4,2 м та 5,6 м $[5,6]$.

Як вважає Акуніна П. І., стандартна розсада перед висаджуванням у відкритий ґрунт для механізованого висаджування повинна бути типовою за забарвленням, міцною, характеризуватись висотою (від кореневої шийки до верхнього листка) 18-25 см і мати 6-8 листків, а маса надземної частини - 13-16 гі кореневої системи $0,6-1,0$ г [7].

Густота стояння рослин впливає на агроекологічні умови їх вирощування: зі збільшенням густоти та зменшенням площі живлення погіршуються умови росту рослини. Під час загущення у рослини спостерігається велика асиміляційна, а отже і поглинаюча поверхня, що призводить то збільшення інтенсивності поглинання мінеральних речовин, води, погіршується освітленість, а також спостерігається зниження амплітуди коливань температури поверхні ґрунту [8].

Матеріали та методи досліджень. Дослідження проводились на дослідному полі кафедри лісового, садово-паркового господарства, садівництва та виноградарства Вінницького національного аграрного університету у

2020-2021 рр. Використовувався ранньостиглий сорт перцю солодкого Афродіта, призначений для споживання у свіжому вигляді. Розсаду віком 50 діб висаджували згідно рекомендацій Інституту овочівництва та баштанництва НАAН на постійне місце вирощування. Для вивчення впливу схем висаджування перцю солодкого на урожайність і біометричні показники обрано рядкову схему розміщення $70 \times 15 \mathrm{~cm}, 70 \times 20,70 \times 30 \mathrm{~cm}$ та стрічкову - 90+50×20 см. За контроль слугували рослини перцю солодкого, які висаджували за схемою $70 \times 20$ см у III-й декаді травня. Під час вегетації визначали: висоту рослини, діаметр стебла, кількість плодів на одній рослині, масу плоду та загальну і товарну врожайність у т/га. Для визначення біометричних показників застосовували лабораторний метод.

Об'єктом досліджень були процеси росту і розвитку рослин перцю солодкого в умовах відкритого ґрунту з використанням методів досліджень - польового і лабораторного.

Виклад основного матеріалу досліджень. Значення біометричних показників значно залежало від схеми розміщення і густоти рослини: чим оптимальнішою вона була, тим показники біометрії були кращими. Така реакція сприяла в тому, що рослини були більш стійкими до стресових ситуацій і могли формувати більшу кількість стандартних плодів. Висота рослин перцю солодкого сорту Афродіта у фазу плодоношення дещо відрізнялась між собою залежно від обраної схеми розміщення. У контролі рослини були типовими, мали відповідне забарвлення, не були пошкодженні хворобами та шкідникам і характеризувались показником 31,1 см. У результаті застосування рядкової схеми $70 \times 15$ см висота рослин збільшилася 
на 4,9 см, проте рослини також характеризувались типовістю забарвлення, стійкістю до хвороб і шкідників.

Враховуючи біометричні показники простежується закономірність, що рослини з більш щільною посадкою чи меншою площею живлення різнилися за показниками біометрії відносно рослин, які вирощувалися з більшою площею живлення. У результаті застосування стрічкової схеми висаджування $90+50 \times 20$ см висота рослини була максимальною і становила 39,1 см, а рядкової схеми $70 \times 30$ см - 32,5 см, що перевищувало контроль на 20,4 см або 4,3 \% відповідно (табл. 1).

Біометричні показники перцю солодкого у фенологічній фазі плодоношення

Таблиця 1 (середнє за 2020-2021 рр.)

\begin{tabular}{|c|c|c|c|c|}
\hline Схема розміщення, см & Висота рослини, см & Діаметр стебла, мм & $\begin{array}{c}\text { Кількість плодів, } \\
\text { шт./росл. }\end{array}$ & Маса плоду, $\boldsymbol{~}$ \\
\hline $70 \times 15$ & $36 \pm 0,1$ & $9,3 \pm 0,2$ & $6,5 \pm 0,1$ & $130,2 \pm 0,1$ \\
\hline $70 \times 20(\kappa)$ & $31,1 \pm 0,2$ & $7,7 \pm 0,2$ & $5,2 \pm 0,1$ & $123,9 \pm 0,2$ \\
\hline $70 \times 30$ & $32,5 \pm 0,1$ & $8,9 \pm 0,1$ & $5,5 \pm 0,1$ & $125,8 \pm 0,1$ \\
\hline $90+50 \times 20$ & $39,1 \pm 0,2$ & $9,5 \pm 0,1$ & $6,8 \pm 0,1$ & $130,7 \pm 0,1$ \\
\hline
\end{tabular}

3 наростанням вегетативної маси рослини важливим показником біометрії вважають діаметр стебла. Чим більший даний показник, тим кращі умови існують для росту і розвитку рослини і формуванні більшої кількості сухої речовини у листках. Більший діаметр стебла отримано за використання рядкової схеми розміщення $70 \times 15$ см та стрічкової 90+50×20 см - 9,3-9,5 мм, що перевищувало контроль на 1,6-1,8 мм. Одночасно, діаметр стебла за використання рядкової схеми розміщення $70 \times 30$ см становив 8,9 мм, проте теж був істотно більшим за показник у контролі на $21 \%$.

Встановлено, що кількість плодів на рослині залежність від схеми розміщення. Так, якщо у контролі за застосування схеми розміщення $70 \times 20$ см загальна кількість плодів складала 5,2 шт., то із застосуванням рядкової схеми $70 \times 30$ см кількість плодів збільшувалось до 5,5 шт. Застосування рядкової схеми розміщення $70 \times 15$ см чи стрічкової схеми $90+50 \times 20$ см загальна кількість плодів на рослині складала 6,5-6,8 шт. відповідно, що було більше за показник у контролі на 20-23\%. Зменшення площі живлення рослини у сорту Афродіта сприяє формуванню більшої кількості плодів.

Одним із важливих показників для рослин перцю солодкого вважають масу плоду. У цілому, плоди за формою, періодом дозрівання відповідали технічній характеристиці сорту, проте середня маса плоду носила змінний характер. Плоди відповідали сортовим вимо- гам, мали типове забарвлення, знаходились у технічній стиглості. Аналіз показника маси плоду коливався в межах від 123,9 г до 130,7 г. Найменшу масу плоду отримано у контролі - 123,9 г, а за застосування рядкової схеми розміщення розсади $70 \times 30$ см досліджуваний показник становив 125,8 г і неістотно перевищував показник у контролі на 1,5%. Одночасно, найбільшою масою плоду характеризувались рослини, які висаджували за рядковою $70 \times 15$ см та стрічковою схемою 90+50×20 см, де показник маси знаходився на рівні 130,2-130,7 г відповідно і перевищував контроль на 6,3-6,8 г.

За отриманими результатами досліджень встановлено залежність урожайності перцю солодкого від схеми розміщення рослин. Плоди відповідали вимогам діючого стандарту, а загальний показник врожайності оцінювався як середній показник і коливався від 24,7 т/га до 30 т/га (табл. 2).

у результаті вирощування розсади перцю солодкого у відкритому ґрунті найвищу врожайність отримали за висаджування рослин за стрічковою схемою розміщення $90+50 \times 20$ см - 30 т/га, що перевищувало контроль на 5,3 т/га або 17,6 \%. Дещо нижчу врожайність отримано за використання рядкової схеми $70 \times 15$ см, де урожайність перевищувала показник у контролі на 16,6 \% і складала 29,6 т/га. Одночасно, рядкова схема 70×30 см забезпечила неістотне зменшення врожайності відносно контролю і досліджуваний показник становив 24,6 т/га.

\begin{tabular}{|c|c|c|c|c|c|}
\multicolumn{7}{c|}{ Урожайність перцю солодкого залежно від схеми розміщення рослин, т/га } \\
(середнє за 2020-2021 рр.)
\end{tabular}

у результаті вирощування перцю солодкого в умовах відкритого ґрунту встановлено відповідність технології вирощування до сортових особливостей рослини, що підтверджується показником коефіцієнта стабільності Левіса. В цілому, цей показник знаходився в межах від 1,02 до 1,16, що засвідчує її типовість для даної зони вирощування. У результаті застосування рядкової схеми розміщення $70 \times 20$ см та $70 \times 15$ см коефіцієнт стабільності Левіса був найвищим і становив 1,07 і 1,16, а за застосу- вання рядкової схеми $70 \times 30$ см та стрічкової $90+50 \times 20$ см показник зменшувався до 1,04 та 1,02 відповідно.

Висновки. 1. Застосування щільного висаджування розсади у відкритому ґрунті рослин перцю солодкого забезпечує збільшення показників біометрії відносно рослин, які вирощувалися з більшою площею живлення.

2. Більший діаметр стебла та більша кількість плодів формувалися на рослині за використання рядкової 70×15 см та стрічкової схеми розміщення $90+50 \times 20$ см, у яких 
показник становить 9,3-9,5 мм та 6,5 і 6,8 шт./росл. відповідно.

3. Середня маса плоду залежить від схеми розміщення рослин: найбільшою вона була за стрічкової схеми $90+50 \times 20$ см та рядкової $70 \times 15$ см - 130,2-130,7 г. 4. У результаті вирощування перцю солодкого з використанням стрічкової схеми розміщення $90+50 \times 20$ см загальна врожайність плодів досягає рівня 30,0 т/га та збільшується відносно контролю на 17 \%. 5. Застосування відповідної технології вирощування перцю солодкого в умовах відкритого ґрунту сприяє отриманню коефіцієнта стабільності Левіса на рівні $1,02-1,16$. Застосування рядкової схеми $70 \times 20$ см чи $70 \times 15$ см збільшує коефіцієнт стабільності Левіса до 1,07-1,16.

\section{Література}

1. Концепції Державної цільової програми розвитку овочівництва на період до 2025 року. М-во аграр. політики та продовольства України. URL: https://zakon. rada.gov.ua/laws/show/1333-2020-\%D1\%80\#Text (дата зверненя: 20.10.2021)

2. Куракса Н.П., Пилипенко Л.В. Параметри адаптивності перцю солодкого. Овочівництво і баштанництво. 2014. Вип. 60. С. 155-166.

3. Кравченко В.А., Приліпко О.В. Перець солодкий. Баклажан: селекція, насінництво, технології. К.: За друга, 2009. 160 с.

4. Насінництво овочевих рослин: навч. посібник / за ред. О. Д. Вітанова. Вінниця: Твори, 2018. 252 с.

5. Шульгина Л. М. Справочник огородника. Харьков: Фолио, 2013. 350 с.

6. Овощи: удобрение, уход, сбор урожая и семян. За ред. Е. Бойка. Харьков: Книжный клуб «Клуб семейного досуга», 2012. 192 с.
7. 10000 советов огороднику. За ред. Н. В. Белова Минск: Современный литератор, 2003. 544 с.

8. Накльока О.П., Калайда К.В. Продуктивність перцю солодкого залежно від схем розміщення і густоти рослин. Таврійський науковий вісник. 2018. №130. С. 99-104.

\section{References}

1. Concepts of the State target program of vegetable development for the period up to 2025 / Ministry of Agriculture. policy and food of Ukraine. URL: https://zakon. rada.gov.ua/laws/show/1333-2020-\%D1\%80\#Text (access date: 20.10 .2021 )

2. Kuraksa N., Pilipenko L. Adaptive parameters of sweet pepper. Vegetable and melon growing. 2014. Vol. 60. P. $155-166$.

3. Kravchenko V., Prilipko O. Sweet pepper. Eggplant: selection, seed production, technologies. Kyiv: Za druga, 2009. $160 \mathrm{p}$

4. Seed production of vegetable plants: textbook. manual. Ed. O. Vitanova. Vinnytsia: Works, 2018. 252 p.

5. Shulgina L. Gardener's Handbook. Kharkiv: Folio, 2013.350 p.

6. Vegetables: fertilization, care, harvesting and seeds. Ed. E. Boyka. Kharkiv: Book Club "Family Leisure Club", 2012. 192 p.

7. 10000 tips for the gardener. ed. N. Belova. Minsk: Contemporary writer, 2003. 544 p.

8. Nakloka O., Kalaida K. Productivity of sweet pepper depending on schemes of arrangement and density of plants. Taurian Scientific Bulletin. 2018. №130.

P. 99-104. 